\title{
Penerapan Teknik Rotoscoping pada Karakter Animasi 2D Pembelajaran Makhraj Huruf Hijaiyah
}

\author{
Application of Rotoscoping Technique in 2D Animation \\ Character of Learning Makhraj Huruf Hijaiyah \\ Ahmad Sarid Ezra Fathin ${ }^{1}$, M. Suyanto ${ }^{2}$, Amir Fatah Sofyan ${ }^{3}$ \\ 1,2,3 Magister Teknik Informatika, Universitas Amikom Yogyakarta \\ E-mail: ${ }^{1}$ ahmad.10@students.amikom.ac.id, ${ }^{2}$ yanto@amikom.ac.id, ${ }^{3}$ amir@amikom.ac.id
}

\begin{abstract}
Abstrak
Indonesia sebagai salah satu negara dengan penduduk muslim terbesar di dunia sangat akrab dengan Bahasa Arab. Penggunaan Bahasa Arab telah menjadi kebutuhan baik untuk beribadah atau penggunaan dalam percakapan sehari-hari. Salah satunya adalah membaca AlQuran. Tidak seperti bacaan yang lain, membaca Al-Qur'an memiliki ketentuan khusus yang harus diperhatikan. Ilmu tersebut dinamakan sebagai ilmu tajwid. Salah satu cabang dalam ilmu tajwid adalah Makhraj Huruf, yaitu ilmu yang mempelajari tentang tempat-tempat keluarnya huruf pada waktu huruf-huruf itu dibunyikan. Mempelajari makhraj huruf dapat dilakukan dengan berbagai cara baik melalui guru secara langsung atau melalui media-media yang tersedia salah satunya dengan animasi. Untuk menghasilkan animasi yang akurat dilakukan teknik rotoscoping dan membandingkannya dengan teknik Auto Lip-Sync sehingga menghasilkan perbandingan baik secara teknis maupun kualitasnya. Parameter pengukuran secara teknis dinilai menggunakan tiga aspek, yaitu frame yang dihasilkan, waktu rendering yang dibutuhkan, dan ukuran file yang dihasilkan. Dari perbandingan tersebut menghasilkan kesimpulan bahwa penggunaan teknik rotoscoping menghasilkan animasi yang nautral dan akurat. Sesuai dengan respon pengguna, animasi ini dapat digunakan sebagai media pembelajaran pendamping karena tidak bisa mengganti cara konvensional dalam belajar makhraj huruf.
\end{abstract}

Kata Kunci-Animasi 2D, Rotoscoping, Auto Lip-sync, Makhraj Huruf, Huruf Hijaiyah,

\begin{abstract}
Indonesia as one of the countries with the largest Muslim population in the world is very familiar with Arabic. The use of Arabic has become a necessity for worship or use in daily conversation. One of them is reading the Quran. Unlike other book, reading the Qur'an has special provisions that must be considered. The knowledge is called tajweed. One branch of tajweed is makhraj huruf, which is the study of the places where letters are released when the letters are sounded. Learning the letters makhraj can be done in various ways either through the teacher directly or through the media available, one of them with animation. To produce an accurate animation rotoscoping technique and compare it with the Auto Lip-Sync technique to produce a comparison both technically and quality. Measurement parameters are technically assessed using three aspects, namely the resulting frame, the required rendering time, and the resulting file size. From these comparisons, it can be concluded that the use of rotoscoping techniques in making animated letters recognition introduces accurate and accurate animations. In accordance with user responses, this animation can be used as a companion of learning because it cannot replace conventional ways of learning letter makhraj.
\end{abstract}

Keywords-2D Animation, Rotoscoping, Auto Lip-Sync, Makhraj Huruf, Hijaiyah Letters 


\section{PENDAHULUAN}

Sebagai salah satu negara dengan penduduk muslim terbesar di Indonesia, penggunaan Bahasa Arab telah menjadi kebutuhan baik untuk beribadah atau penggunaan dalam percakapan sehari-hari. Salah satunya adalah membaca Al-Quran. Tidak seperti bacaan yang lain, membaca Al-Qur'an memiliki ketentuan khusus yang harus diperhatikan. Ilmu tersebut dinamakan sebagai ilmu tajwid. Salah satu cabang dalam ilmu tajwid adalah Makhraj Huruf, yaitu ilmu yang mempelajari tentang tempat-tempat keluarnya huruf pada waktu huruf-huruf itu dibunyikan [1]. Yang tidak dapat terpisahkan dari mempelajari Makhraj huruf adalah Ilmu Fonetik Arab (Bunyi bahasa) yang dapat disinergikan ke dalam pembelajaran tajwid Al-Quran [2].

Mempelajari makhraj huruf dapat dilakukan dengan berbagai cara baik melalui guru secara langsung atau melalui media-media yang tersedia. Salah satunya adalah aplikasi android yang dapat memudahkan dan menarik perhatian pengguna dalam mempelajari Makhraj Huruf Hijaiyah [3].

Tidak hanya sebagai hiburan, video animasi juga sering kali dijadikan sebagai media pembelajaran. Penggunaan media animasi dapat menjadi alternatif video live shot untuk mempelajari makhraj huruf. Penggunaan animasi sebagai media pembelajaran makhraj huruf dapat meningkatkan pengucapan huruf hijaiyah yang benar sesuai dengan makhrajnya [4]. Hal yang harus diperhatikan dalam mempelajari makhraj adalah gerakan bibir. Pembuatan video yang terdapat lipsync karakter didalamnya dibutuhkan kemampuan yang akurat untuk menyinkronkan gerakan bibir ke ucapan audio karena merupakan aspek penting dalam karakter virtual [5]. Karena pembuatan animasi 2D pembelajaran makhraj mengandalkan keakuratan gerak bibir dibutuhkan teknik pembuatan animasi yang bisa mentransformasikan video live shot ke video animasi.

Ada banyak teknik pembuatan animasi salah satunya teknik rotoscope. Penggunaan teknik rotoscope untuk model cerita yang realis dirasa tepat karena suasana yang dibentuk mirip dengan kehidupan nyata, sehingga penonton mempunyai kedekatan secara visual [6]. Penelitian lainnya mengungkapkan bahwa dampak dari teknik rotoscoping adalah dapat digunakan secara maksimal untuk menghasilkan gerakan animasi yang lebih natural dan berkualitas pada pembuatan animasi 2D [7]. Untuk menghasilkan hasil rotoscope yang baik dibutuhkan penegasan dan penandaan terhadap sudut-sudut objek yang ditangkap karena jelas atau tidaknya sudut objek yang ditandai mempengaruhi hasil animasi [8].

Dari latar belakang di atas, penulis mencoba untuk melakukan penelitian terkait Penerapan Teknik Rotoscoping Pada Karakter Animasi 2D Pembelajaran Makhraj Huruf Hijaiyah.

\section{METODE PENELITIAN}

\subsection{Metode Penelitian}

Dalam penelitian ini penulis menggunakan metode Research and Development (R\&D). Data yang diuji yaitu tingkat efektifitas dan animasi yang dihasilkan dengan membandingkan teknik rotoscoping dan teknik lainnya yang hasilnya akan dianalisis sehingga menemukan cara yang paling efektif.

Riset pengembangan atau Research and Development bertujuan untuk mengembangkan, menguji kemanfaatan dan efektifitas produk (model) yang dikembangkan, baik produk teknologi, material, organisasi, metode, alat-alat dan sebagainya. Sebagai riset terapan, riset pengembangan bertujuan bukan untuk untuk menghasilkan teori. Oleh karena itu, dalam penelitian pengembangan sangat dimungkinkan untuk menggunakan multi pendekatan atau multi metode [9]. 


\subsubsection{Metode Pengumpulan Data}

Pengumpulan data dalam penelitian ini dilakukan dengan melakukan eksperimen. Selain itu, data-data lainnya juga didapat dengan melakukan observasi sebagai referensi misalnya dalam perancangan bentuk-bentuk mulut yang dibutuhkan dalam makhraj huruf. Serta mewawancarai praktisi dalam bidang yang bersangkutan. Selain mengumpulkan informasi, data utama yang dibutuhkan dalam penelitian ini adalah video dan audio. Video liveshot diperlukan untuk menerapkan metode rotoscoping sebagai referensi saat menggambar. Video diambil dengan kamera standar menggunakan tripod yang berhadapan dengan objek dalam hal ini yaitu pengajar/ ahli dalam ilmu tajwid. Objek diambil dengan berfokus kepada area wajah karena titik fokus objek yang dibutuhkan berada pada perubahan bentuk mulut saat mengucapkan huruf-huruf hijaiyah.

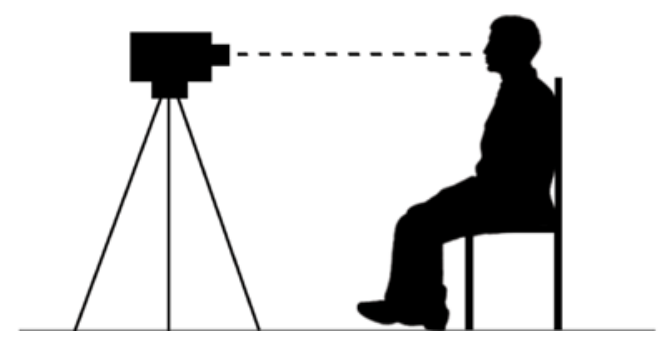

Gambar 1. Sudut Pengambilan Gambar

Alat-alat yang digunakan dalam eksperimen mencakup komputer dan kamera dengan spesifikasi standar serta software Toon Boom Harmony untuk pembuatan animasi. Pengumpulan data juga menggunakan metode angket untuk mengetahui pendapat/ respon tentang penggunaan rotoscoping sebagai media pembelajaran.

Dalam penelitian ini wawancara dilakukan dengan praktisi di bidang animasi 2D. Fokus dalam wawancara ini adalah untuk mengetahui metode dalam pembuatan animasi dua dimensi dan dasar-dasar animasi dua dimensi.

Selain itu dilakukan metode studi literatur untuk mencari dan mempelajari teori-teori, konsep-konsep yang ada relevansinya dengan permasalahan penelitian ini. Sumber yang berasal dari kepustakaan dapat dibedakan menjadi dua yaitu sumber umum dan sumber khusus. Sumber umum dapat ditemukan dalam buku-buku teks, ensiklopedia, dan internet. Sumber khusus dapat berupa hasil-hasil penelitian yang telah dilakukan dengan masalah yang relevan dengan penelitian yang sedang dilakukan.

\subsection{2. $\quad$ Metode Analisis Data}

Metode untuk menganalisis data pada penelitian ini adalah metode perbandingan yaitu membandingkan hasil eksperimen dari dua teknik yang meliputi lama pengerjaan, render, besar file yang dihasilkan, hingga kualitas hasil dari masing-masing teknik. Dari perbandingan itulah dapat ditentukan metode mana yang lebih efektif. Teknik yang digunakan yaitu teknik rotoscoping dan auto lip-sync yang telah tersedia.

\subsection{Implementasi Teknik}

Implementasi teknik dilakukan dengan cara menguji dua metode yang digunakan yaitu metode rotoscoping dan Auto Lip-Sync. Kedua metode dilakukan pada software Toon Boom Harmony dan dengan komputer spesifikasi standar.

\subsubsection{Teknik Rotoscoping}

Rotoscoping merupakan salah satu teknik animasi yang menggunakan hasil jiplakan gerakan film manusia (bukan animasi) secara frame by frame yang digunakan oleh animator untuk menghasilkan film animasi [10]. 
Penggunaan teknik ini berkaitan dengan video animasi yang akan diproduksi yang bersifat realis atau mirip dengan kehidupan nyata. Teknik rotoscope menghasilkan gaya visual yang realis karena gambar yang dibentuk berdasarkan gambar hasil perekaman adegan secara nyata.

Rotoscoping dilakukan dengan menginput langsung video berformat mov. yang sudah dipisahkan sesuai dengan jenis makhraj. Setelah itu, video akan terpisah menjadi frame by frame. Langkah selanjutnya adalah tracing atau menggambar ulang frame by frame di atas layer video sesuai dengan pergerakan pada video. Proses inilah yang dinamakan rotoscoping seperti yang terlihhat pada Gambar 2.

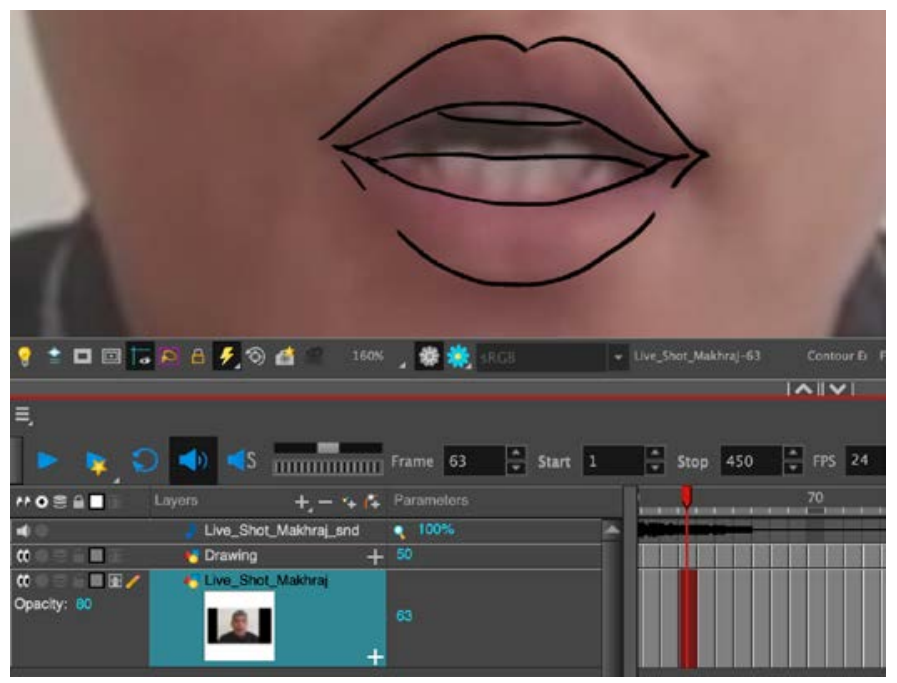

Gambar 2. Proses Rotoscoping

Teknik ini menghasilkan animasi yang natural karena gerakan yang dihasilkan sesuai dengan video live shot. Teknik rotoscoping membutuhkan waktu yang lama karena harus menggambar frame by frame.

Semua proses dilakukan secara digital dengan menggunakan Toon Boom Harmony dan alat input pen tablet untuk menggambar atau tracing. Kualitas video mempengaruhi kenyamanan saat melakukan proses rotoscoping. Salah satu hasil dari proses rotoscoping dapat dilihat pada Gambar 3.

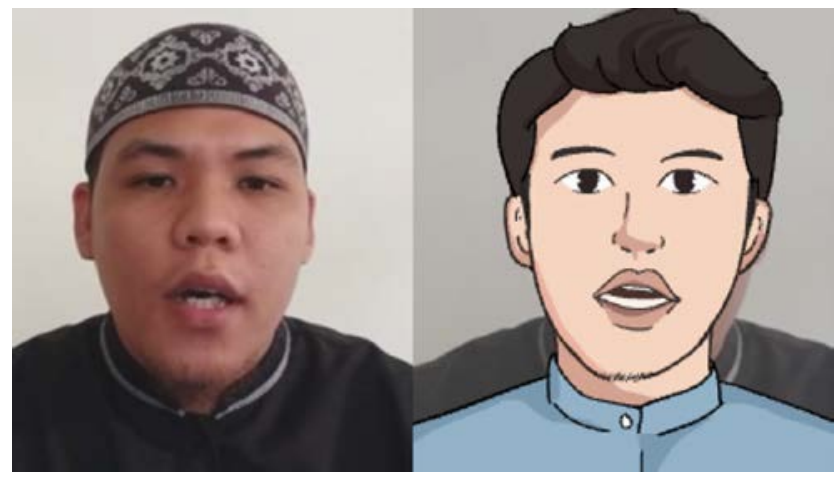

Gambar 3. Hasil Rotoscoping

Keunggulan teknik rotoscoping adalah dapat menghasilkan animasi yang realistis karena dilakukan tracing frame by frame. Selain menghabiskan waktu yang lama, kekurangan teknik ini yang digunakan untuk membuat animasi pergerakan mulut adalah saat menggabungkannya dengan background karakter yang telah dibuat sebelumnya. 


\subsubsection{Teknik Auto Lip-Sync}

Lip-Sync atau lip synchronization adalah istilah teknis dari pencocokan gerakan bibir dengan audio atau pengucapan vokal yang telah direkam sebelumnya. Dalam ranah animasi, lipsync dapat disebut sebagi seni dalam membuat animasi karakter yang dapat berbicara berdasarkan track rekaman atau dialog secara tepat. Teknik lip-sync dalam animasi pertama kali diperkenalkan oleh Max Fleischer pada tahun 1926 dalam My Old Kentucky Home dan penggunaanya terus berlanjut hingga sekarang.

Dalam produksi film, lip-sync dimasukkan dalam bagian post-production. Dubbing film dengan bahasa asing dan membuat animasi karakter yang dapat berbicara menggunakan teknik lip-sync. Beberapa video game menggunakan lip-sync dalam karakter untuk memberikan efek lingkungan yang immersive.

Auto Lip-Sync merupakan salah satu fitur dari perangkat lunak Toon Boom Harmony yang dapat menambahkan lip-sync karakter yang bersumber dari suara. Teknik ini memungkinkan pengguna untuk membuat pergerakan mulut animasi sesuai dengan audio yang diinputkan tanpa harus menggambar frame by frame. Hal utama yang perlu disiapkan untuk menggunakan fitur ini adalah audio dengan format .mp3, .aiff, dan .wav. Selain itu dibutuhkan background berupa wajah tampak depan tanpa mulut.

Hal terpenting lain adalah macam-macam jenis mulut sesuai dengan fonemnya seperti pada Gambar 4. Jumlah bentuk mulut yang dibutuhkan adalah delapan buah.

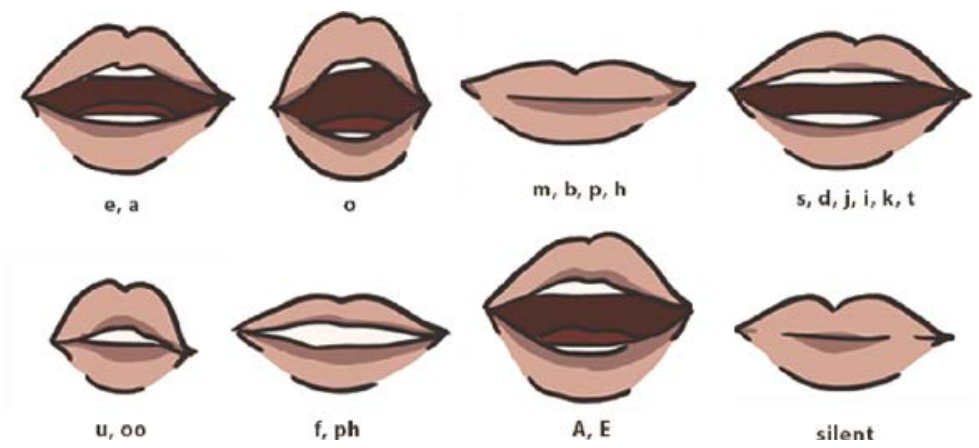

Gambar 4. Bentuk Mulut Berdasarkan Pelafalan

Teknik ini membutuhkan audio untuk bisa digunakan. Animasi yang dihasilkan oleh teknik ini bersifat cut-out yaitu menggabungkan beberapa gambar membentuk stop motion. Keunggulan teknik ini adalah animasi dihasilkan dengan cepat dan otomatis. Gambar 5 merupakan contoh hasil Auto Lip-Sync.

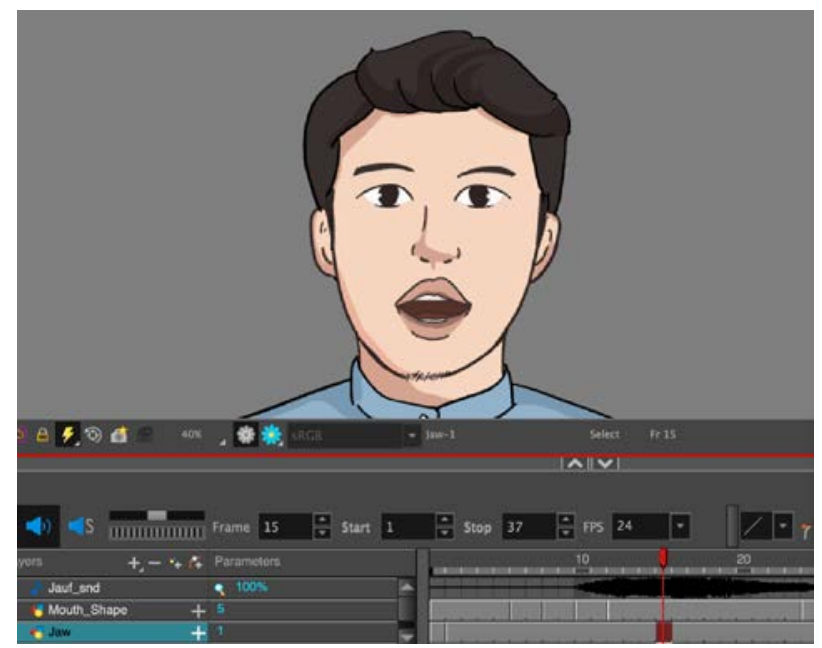

Gambar 5. Hasil Auto Lip-Sync 
Meskipun waktu yang dibutuhkan dengan teknik ini lebih cepat, hal yang menjadi kekurangannya adalah bentuk mulut yang dihasilkan sering kali salah jika dibandingkan dengan suara yang dikeluarkan. Suara yang jernih dan jelas menjadi penentu keberhasilan teknik ini.

\section{HASIL DAN PEMBAHASAN}

\subsection{Perbandingan Teknik}

Untuk membandingan keefisienan dua teknik menggunakan metode pendekatan Skala Likert. Parameter pengukuran dinilai menggunakan tiga aspek, yaitu:

1. Jumlah frame yang dihasilkan

2. Waktu Rendering yang dibutuhkan

3. Ukuran File yang dihasilkan.

Pada teknik rotoscoping, secara teknik menghasilkan data sesuai dengan aspek yang digunakan terlihat pada Tabel 1.

Tabel 1. Teknik Rotoscoping

\begin{tabular}{lccc}
\hline Jenis Makhraj & Frame (24f/s) & Waktu Render (s) & Ukuran File (KB) \\
\hline Al Jauf (و) & 48 & 3,70 & 548 \\
\hline Al Halq (ح) & 57 & 4,01 & 480 \\
\hline Al Lisan (ش) & 65 & 3,35 & 561 \\
\hline Asy-Syafatan (ب) & 58 & 4,21 & 605 \\
\hline Al-Khaisyum (ن) & 45 & 3,54 & 453 \\
\hline
\end{tabular}

Pada teknik rotoscoping, secara teknik menghasilkan data sesuai dengan aspek yang digunakan terlihat pada Tabel 2.

Tabel 2. Teknik Auto Lip-Sync

\begin{tabular}{lccc}
\hline \multicolumn{1}{c}{ Jenis Makhraj } & Frame (24f/s) & Waktu Render (s) & Ukuran File (KB) \\
\hline Al Jauf (و) & 37 & 2,02 & 383 \\
\hline Al Halq (ح) & 45 & 2,07 & 428 \\
\hline Al Lisan (ش) & 54 & 2,06 & 461 \\
\hline Asy-Syafatan (ب) & 47 & 2,36 & 430 \\
\hline Al-Khaisyum (ن) & 35 & 2,43 & 372 \\
\hline
\end{tabular}

Kedua tabel tersebut menunjukkan hasil yang dibagi berdasarkan jenis makhraj dengan mengambil satu huruf hijaiyah sebagai sampel tiap makhraj. Tabel menunjukkan bahwa teknik rotoscoping secara relatif menghasilkan frame yang lebih banyak daripada teknik Auto Lip-Sync. Begitu pula waktu yang dibutuhkan untuk rendering sampai dengan ukuran file yang dibutuhkan. Perbandingan tersebut dapat dilihat pada grafik Gambar 4.

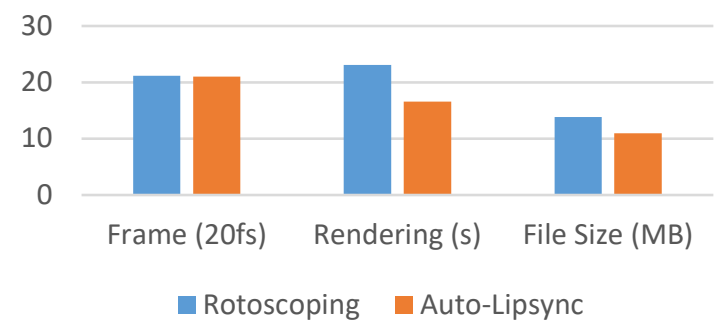

Gambar 4. Perbandingan Rerata tiap Metode 
Grafik pada Gambar 4. menunjukkan bahwa secara teknis, teknik Auto Lip-Sync lebih efisien digunakan dibandingkan dengan teknik rotoscoping. Efisien dalam waktu pengerjaan ataupun besaran file yang dihasilkan. Terlihat bahwa untuk frame yang dihasilkan, teknik rotoscoping lebih banyak daripada teknik auto lip-sync. Begitu pula dengan waktu render dan file size yang dihasilkan oleh teknik rotoscoping lebih dari teknik auto lip-sync.

Dari segi pengamatan secara langsung, perbedaan mendasar yang terlihat dari kedua teknik ini adalah pergerakan animasinya. Pada teknik rotoscoping, animasi pada mulut yang dihasilkan lebih natural karena pergerakannya mengikuti video live shot. Selain itu, teknik ini juga dapat memberikan detail yang lain seperti pergerakan naik turunnya rahang yang akan membuat animasi lebih natural. Pada teknik Auto Lip-Sync, pergerakan animasi bersifat cut-out yang membuat animasi terlihat jelas pergantian dari satu frame ke frame yang lain. Keunggulan teknik ini adalah pergenrakan mulut yang dihasilkan konsisten.

\subsection{Publikasi}

Sebelum dipublikasi kepada pengguna, media pembelajaran pengenalan makhraj huruf hijaiyah berbasis animasi dibuat dengan menggabungkan animasi, teks, dan suara menjadi satu kesatuan. Compositing atau penggabungan beberapa elemen tersebut dilakukan di Adobe After Effects.

Untuk mendapatkan audiensi yang banyak, perlu dilakukan publikasi ke beberapa media sosial. Dalam penelitian ini dilakukan di Youtube dan Instagram. Pemilihan dua sosial media itu karena popular dan relevan dengan target pengguna dan pengguna bebas mengakses kapanpun.

\subsection{Tanggapan Pengguna}

Tanggapan pengguna adalah suatu proses pengujian oleh pengguna yang bertujuan untuk mengetahui apakah animasi yang telah dibuat dapat diterima oleh pengguna. Pengguna melakukan penilaian terhadap animasi dengan menggunakan media kuesioner. Kuesioner diberikan kepada pengguna media animasi pengenalan makhraj huruf, dengan jumlah 50 dan dari hasil kuesioner tersebut dilakukan perhitungan dan kesimpulan.

Berdasarkan hasil kuesioner dapat disimpulkan bahwa animasi pengenalan makhraj huruf hijaiyah, telah disetujui oleh para responden sebagai media yang dapat membantu para responden dalam mempelajari huruf hijaiyah yang artinya animasi sudah dapat memenuhi tujuan utama dalam membantu dan memudahkan penggunanya untuk mengenal makhraj huruf hijaiyah. Selain itu, media animasi tidak bisa menggantikan cara konvensional menurut pengguna yang paling banyak memilih tidak setuju pada pertanyaan apakah media ini bisa mengganti cara konvensional mempelajari huruf hijaiyah.

\section{KESIMPULAN}

Dari penelitian yang dilakukan dapat diambil beberapa kesimpulan:

1. Penggunaan teknik rotoscoping untuk membuat animasi pengenalan makhraj huruf menghasilkan pergerakan mulut yang natural karena mengikuti video referensi frame by frame. Untuk menggunakan teknik rotoscoping dibutuhkan kualitas video yang memadai sehingga detail dapat digambar secara lebih maksimal.

2. Penggunaan animasi sebagai pembelajaran pengenalan makhraj huruf hijaiyah layak digunakan, tetapi hanya sebagai media pendamping.

3. Dari kuesioner yang tersebar, responden setuju bahwa animasi ini dapat memudahkan penggunanya dalam mengenal makhraj huruf hijaiyah.

4. Secara teknis, teknik Auto Lip-Sync lebih efisien digunakan dibandingkan dengan teknik rotoscoping. Efisien dalam waktu pengerjaan ataupun besaran file yang dihasilkan. Untuk animasi pengenalan makhraj huruf hijaiyah, teknik rotoscoping lebih cocok digunakan dibandingkan Auto Lip-Sync karena animasi pergerakan mulut yang dihasilkan lebih akurat. 


\section{SARAN}

Untuk penelitian selanjutnya yang dapat dilakukan antara lain:

1. Pengembangan animasi pembelajaran dapat dilakukan dengan melengkapi semua huruf makhraj beserta contoh-contohnya.

2. Pengembangan selanjutnya juga dapat dilakukan dengan membuat animasi berdasarkan gender ataupun umur sehingga animasi lebih tepat sasaran.

3. Pengembangan aplikasi pengenalan makhraj huruf yang lebih interaktif berbasis mobile seperti Android dan iOS.

\section{DAFTAR PUSTAKA}

[1] Kurnaedi, A. Y., Jabal, N. S., 2014, Metode Asy-Syafi'i - Ilmu Tajwid Praktis, Pustaka Imam Asy-Syafi'i, Jakarta

[2] Baharudin, H., Lubis, M. A., Yusoff, M. N. R. N., 2018, Tajweed Learning Through the Support of Arabic Phonetic (Pembelajaran Tawjid Melalui Sokongan Fonetik Arab), Jurnal Hadhari, No. 2, Vol. 10.

[3] Hompu, U. M. L., Yamin, M., Sagala, L. O. H. S., 2016, Multimedia Pembelajaran Interaktif Makhraj Huruf Hijaiyah, Wudu, dan Salat Menggunakan Adobe Flash CS6 berbasis Mobile Android, semanTIK, Vol.2, No.2, Hal. 103-114.

[4] Saputra, D. A., 2017, Pengembangan Aplikasi Pembelajaran Makhorijul Huruf Hijaiyah Berbasis Animasi, Skripsi, Teknologi Informasi Fakultas Teknik, Universitas Muhammadiyah Yogyakarta

[5] Llorach, G., Evans, A., Blat, J., Grimm, G., Hohmann, V., 2016, Web-Based Live SpeechDriven Lip-Sync, 2018 Conference on Games and Virtual Worlds for Serious Applications, Wurzburg, 05 Septeber

[6] Rahman, F., Suminto, M., Purwacandra, P. P., 2017, "Burnout” Animasi Dua Dimensi Dengan Teknik Rotoscope, Journal of Animation and Games Studies, NO. 2, Vol.3.

[7] Ifraweri, 2018, Rancang Bangun Film Animasi 2D dengan Metode Rotoscoping Live Shot, Tesis, Magister Teknik Informatika, STMIK AMIKOM, Yogyakarta

[8] Murphy, I., Norlund, T., Pallipuram, V. K., 2017, A Best-Features based Digital Rotoscope, 2017 51st Asilomar Conference on Signals, Systems, and Computers, Pacific Grove, 29 October 29 - 1 November

[9] Hasibuan, Z. A., 2007, Metodologi Penelitian Pada Bidang Ilmu Komputer Dan Teknologi Informasi, Fakultas Ilmu Komputer, Universitas Indonesia

[10] Binanto, I., 2010, Multimedia Digital - Dasar Teori dan Pengembangannya, Andi Offset, Yogyakarta 